\title{
Vegetable Safety Risk Early-warning Model Based on Fault Tree
}

Tingxin Wang ${ }^{1, a}$, Xiaoyang Li ${ }^{1, b}$, Qingchi Meng ${ }^{2, c}$ and Haihong Xin ${ }^{1, d}$

${ }^{1}$ College of Quality \& Technical Supervision, Hebei University, Baoding 071000, China

${ }^{1}$ Baoding engineering technology research center of dairy research development and quality control, Baoding 071000, China

${ }^{2}$ Office of Judicial technology, Baoding intermediate court, Baoding 071000, China

atingxinwang@126.com, b821044985@qq.com, cmengqch@126.com, d451717492@qq.com

Keywords: Fault tree analysis; Vegetable safety; Risk early-warning; Risk analysis

\begin{abstract}
This paper introduced the fault tree analysis method and its application, analyses various factors of vegetable safety status and safety problems caused by vegetables, establishes the fault tree of the vegetable safety, and for this fault tree do some qualitative and quantitative analysis, combines the theory of risk analysis, and then establish vegetable safety risk early-warning model based on fault tree analysis. This model aims to predict severity of the hazards and take measures to reduce the harm may occur. In this context, this not only broadens the application domain of fault tree analysis, but also provides a reference for the safety of vegetables in the future.
\end{abstract}

\section{Introduction}

Fault tree analysis (FTA) is a kind of typical graph deductive method, is the failure event under certain conditions of logical reasoning method. It is in the process of system design, through to the system failure caused by various factors, including hardware, software, environment, human factors) is analyzed, draw the logic diagram (fault tree), and thus gradually in-depth analysis, to determine system failure reason of all possible combinations or its probability of occurrence, take appropriate corrective action, in order to improve the system reliability of a kind of design method.

\section{Vegetable Safety Fault Tree}

Based on the various factors of vegetable safety problem is analyzed, vegetable safety problems is established. As shown in Fig. 1:

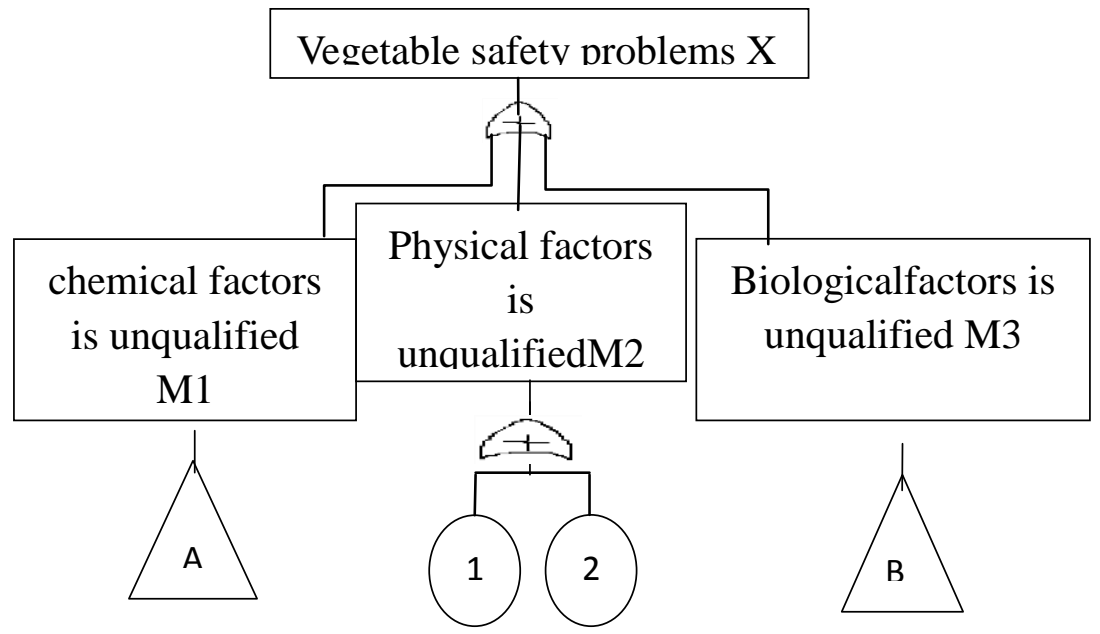

Figure 1. Vegetable safety fault tree 
Table 1 The fault tree bottom event in vegetable safety problem

\begin{tabular}{ll}
\hline The serial number & The name of the event \\
1 & Soft foreign body detected (Hair, insects, etc) \\
2 & A hard foreign body detection(Sand, stones, metal wire, \\
etc)
\end{tabular}

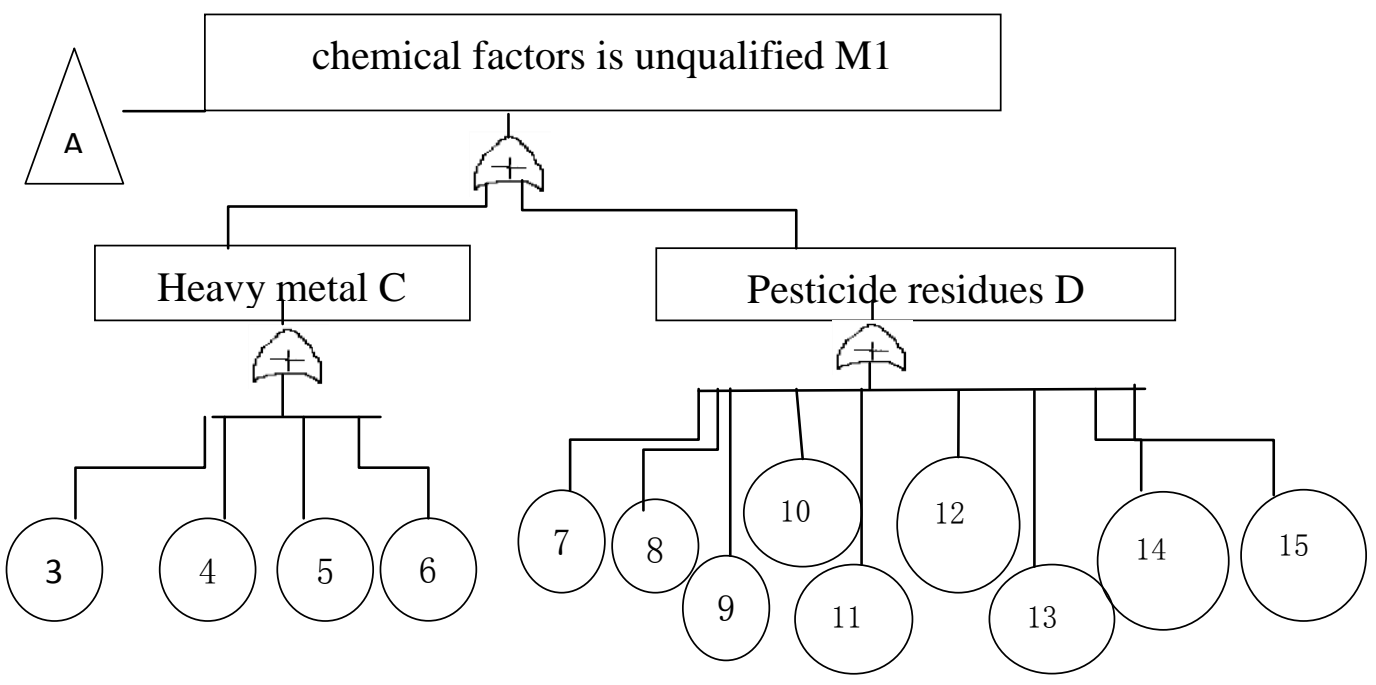

Figure 2. Unqualified chemical factors in the fault tree

Because there are many different kinds of pesticides, only choose frequent pesticide residue as the bottom events. As shown in Table 2:

Table 2 Unqualified chemical factors in the fault tree bottom event

\begin{tabular}{ll}
\hline The serial number & The name of the event \\
\hline 3 & Lead \\
4 & Cadmium \\
5 & Mercury \\
6 & Arsenic \\
7 & Omethoate \\
8 & Mocap \\
9 & Long acting phosphorus \\
10 & Dichlorvos \\
11 & Methamidophos \\
12 & Methyl parathion \\
13 & Acephate \\
14 & 1-Naphthalenyl methyl carbamate \\
15 & Gram bud \\
\hline
\end{tabular}




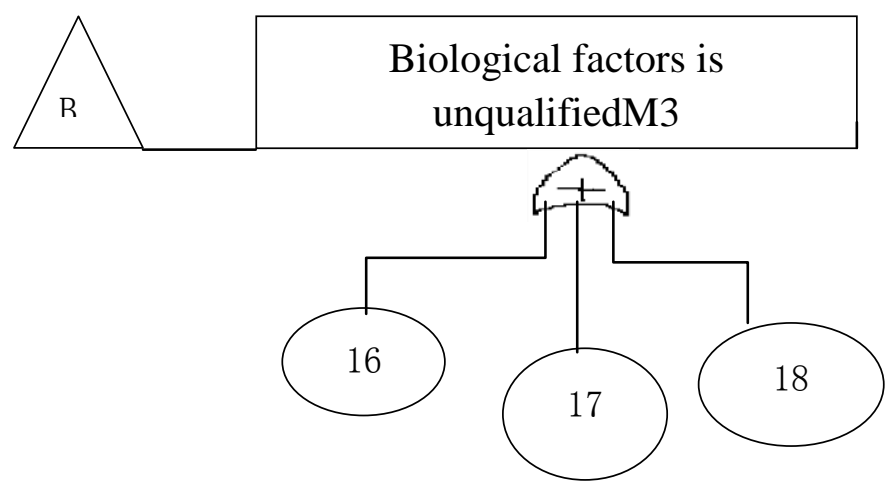

Figure 3. Unqualified fault tree biological factors

Table 3 Biological factors unqualified fault tree bottom event

\begin{tabular}{ll}
\hline The serial number & The name of the event \\
\hline 16 & E. coli and total number of E. coli \\
17 & The parasite \\
18 & salmonella \\
\hline
\end{tabular}

\section{Vegetable Safety Fault Tree Analysis}

(1) The Qualitative Analysis. Fault tree qualitative analysis is to qualitatively identify top events all possible failure modes, namely, the minimum cut sets of fault tree. Cut set is a set of basic events that guide the top events. That is to say, in the fault tree of a set of basic events, can cause the top event; this set of basic events is called cut set. A collection of some of the fault tree bottom event, when these events occur, top events occur inevitably. Minimum cut set is arbitrary cut concentration of the bottom events if remove one ceases to be cut.

For the fault tree of minimum cut set method has a downward and upward method. Descending method from top to bottom is start from the top event list replacement method step by step, While the upstream method is bottom-up using a collection of simplified operation rules, finally find out the minimum cut set from the simplified type. This article uses the ascending method for qualitative analysis.

By Figure 3-2, Figure 3-3 and Figure 3-4,

$\mathrm{M} 3=16+17+18, \mathrm{C}=3+4+5+6, \mathrm{D}=7+8+9+10+11+12+13+14+15$,

Upgrade level calculated:M1 $=\mathrm{C}+\mathrm{D}, \mathrm{M} 2=1+2$,

The top event is obtained:

$\mathrm{X}=\mathrm{M} 1+\mathrm{M} 2+\mathrm{M} 3=1+2+3+4+5+6+7+8+9+10+11+12+13+14+15+16+17+18$ 。

Conclusion: the minimum cut set of the fault tree are $\{1\},\{2\},\{3\},\{4\},\{5\},\{6\},\{7\},\{8\},\{9\}$, $\{10\},\{11\},\{12\},\{13\},\{14\},\{15\},\{16\},\{17\},\{18\},\{19\}$ 。

(2) Quantitative Analysis. Quantitative analysis of fault tree there are two major aspects: First, the failure probability of the system is calculated, second, The structure, key and probability importance of each base event are calculated.

First, the failure probability of the system is calculated: we assume that the system exists $n$ minimum cut sets, respectively, E1, E2, E3, EN. Then the system failure probability of top event X is $: \mathrm{P}(\mathrm{X})=\mathrm{P}\left(\mathrm{E} 1 \uplus^{\uplus} \mathrm{E} 2 \uplus \ldots \uplus \mathrm{H} \mathrm{En}\right)=\mathrm{P}\left(\mathrm{E} 1+\mathrm{E} 1^{\prime} \mathrm{E} 2+\mathrm{E} 1^{\prime} \mathrm{E} 2^{\prime} \mathrm{E} 3+\ldots \mathrm{E} 1^{\prime} \mathrm{E} 2^{\prime} \ldots \mathrm{En}-1^{\prime} \mathrm{En}\right)[13]$ 。

Then, in the general case, quantitative analysis of fault tree, we only need to calculate the system failure probability, And in this paper, the structure, the probability of the basic events and key importance no application, in this not do a detailed analysis. 


\section{Level of Risk Evaluation}

Degree of risk $=$ hazard occurrence possibility $\mathrm{L}^{*}$ hazard consequences severity $\mathrm{S}$. The division of risk grade of vegetables and the countermeasures of different risk grades are listed in Table 4:

Table 4 Risk grade classification

Risk degree Grade Behavior control measures should be taken.

\begin{tabular}{lll}
\hline 20-25 & Huge risk & $\begin{array}{l}\text { Immediately take measures to reduce the hazards, identify } \\
\text { the key reasons, and focus on the control of. }\end{array}$ \\
\hline 15-16 & $\begin{array}{l}\text { Major } \\
\text { risk }\end{array}$ & $\begin{array}{l}\text { Take emergency measures to reduce risk, establish } \\
\text { operational control procedures, regular inspection, } \\
\text { measurement and evaluation. }\end{array}$ \\
\hline $9-12$ & secondary & $\begin{array}{l}\text { Strengthen supervision and control, always pay attention to } \\
\text { the trend of risk change, and strive to low risk. }\end{array}$ \\
\hline $4-8$ & $\begin{array}{l}\text { Can be } \\
\text { tolerated }\end{array}$ & $\begin{array}{l}\text { Can consider the establishment of production, circulation } \\
\text { and storage specifications, to maintain the existing level, } \\
\text { no conversion to the high level of risk. }\end{array}$ \\
\hline$<4$ & $\begin{array}{l}\text { Slight or } \\
\text { negligible }\end{array}$ & $\begin{array}{l}\text { Control measures are not required, but record keeping is } \\
\text { required. }\end{array}$ \\
\hline
\end{tabular}

The probability of occurrence of the hazard and the probability of the top event of the fault tree is shown in Table 5, Table 6.

Table 5 The possibility of hazard occurrence L division

\begin{tabular}{llllll}
\hline Probability $(\mathrm{P})$ & $<0.1$ & $0.1 \sim 0.25$ & $0.25 \sim 0.5$ & $0.5 \sim 0.75$ & $0.75 \sim 1$ \\
\hline Likelihood $(\mathrm{L})$ & 1 & 2 & 3 & 4 & 5 \\
\hline
\end{tabular}

\section{Control Measures Taken}

Table 4 shows, for the medium risk, we should strengthen the supervision and control, focus on the risk change trend, and strive to low risk. Put forward specific control measures: for dealer, it should strengthen the source of the monitoring of vegetables, the sale of high-quality vegetables; For producers, it should be strictly in accordance with the requirements of the use of chemical fertilizers and pesticides, do not use highly toxic and even banned pesticides, do not use contaminated water for irrigation, and need to know about the soil of growing vegetables, not to grow vegetables in contaminated soil; for consumers, should improve their awareness of the safety of vegetables, do not blindly listen to a variety of media and advertising, have their own judgment, get the knowledge of vegetable safety through multi channels. 
Table 6 Serious harmful consequences of S division

\begin{tabular}{|c|c|c|c|c|c|c|}
\hline Grade & $\begin{array}{l}\text { Feeling and } \\
\text { reaction } \\
\text { after human } \\
\text { consumption }\end{array}$ & $\begin{array}{l}\text { Chemical } \\
\text { hazard }\end{array}$ & $\begin{array}{l}\text { Physical } \\
\text { hazard }\end{array}$ & $\begin{array}{l}\text { Biological } \\
\text { hazard }\end{array}$ & $\begin{array}{l}\text { The } \\
\text { cognition } \\
\text { of } \\
\text { vegetable } \\
\text { safety }\end{array}$ & $\begin{array}{l}\text { The spread of } \\
\text { knowledge about } \\
\text { the safety of } \\
\text { vegetables }\end{array}$ \\
\hline 5 & $\begin{array}{l}\text { Poisoning is } \\
\text { strong, and } \\
\text { even death. }\end{array}$ & $\begin{array}{l}\text { Have a lot } \\
\text { of heavy } \\
\text { metals and } \\
\text { pesticide } \\
\text { residue } \\
\text { detection }\end{array}$ & $\begin{array}{l}\text { There are } \\
\text { non } \\
\text { natural hard } \\
\text { objects, such } \\
\text { as: metal } \\
\text { wire, etc. }\end{array}$ & $\begin{array}{l}\text { Detection of } \\
\text { a variety of } \\
\text { pathogenic } \\
\text { bacteria, and } \\
\text { excessive }\end{array}$ & Very low & $\begin{array}{l}\text { Knowledge or } \\
\text { point of view is } \\
\text { wrong, } \\
\text { misleading } \\
\text { people }\end{array}$ \\
\hline 4 & $\begin{array}{l}\text { Toxic } \\
\text { reactions } \\
\text { can be } \\
\text { alleviated by } \\
\text { treatment }\end{array}$ & $\begin{array}{l}\text { Heavy } \\
\text { metals and } \\
\text { pesticide } \\
\text { residues } \\
\text { were } \\
\text { detected in } \\
1-2\end{array}$ & $\begin{array}{l}\text { There is a } \\
\text { natural hard } \\
\text { body, such } \\
\text { as: soil }\end{array}$ & $\begin{array}{l}\text { Detection of } \\
\text { a pathogenic } \\
\text { bacteria, and } \\
\text { excessive }\end{array}$ & $\begin{array}{l}\text { Relatively } \\
\text { low }\end{array}$ & $\begin{array}{l}\text { There is no } \\
\text { scientific basis, } \\
\text { so that people } \\
\text { develop false } \\
\text { consciousness }\end{array}$ \\
\hline 3 & $\begin{array}{l}\text { No toxic } \\
\text { reaction, but } \\
\text { the feeling is } \\
\text { not suitable }\end{array}$ & $\begin{array}{l}\text { Heavy } \\
\text { metal or } \\
\text { pesticide } \\
\text { residues } \\
\text { were } \\
\text { detected } \\
1-2, \text { and } \\
\text { exceeded }\end{array}$ & $\begin{array}{l}\text { Have a soft } \\
\text { non-natural } \\
\text { foreign } \\
\text { body, such } \\
\text { as: hair }\end{array}$ & $\begin{array}{l}\text { Two } \\
\text { pathogenic } \\
\text { bacteria were } \\
\text { detected, but } \\
\text { not } \\
\text { exceeding } \\
\text { the standard. }\end{array}$ & low & $\begin{array}{l}\text { Don't get close } \\
\text { to the life, not } \\
\text { essential }\end{array}$ \\
\hline 2 & $\begin{array}{l}\text { Taste in } \\
\text { general, } \\
\text { adverse } \\
\text { effects on } \\
\text { the body }\end{array}$ & $\begin{array}{l}\text { Heavy } \\
\text { metal or } \\
\text { pesticide } \\
\text { residues } \\
\text { were } \\
\text { detected, } \\
\text { but not } \\
\text { exceeding }\end{array}$ & $\begin{array}{l}\text { There are } \\
\text { soft natural } \\
\text { foreign } \\
\text { bodies, such } \\
\text { as insects }\end{array}$ & $\begin{array}{l}\text { Detection of } \\
\text { a pathogenic } \\
\text { bacteria, but } \\
\text { not excessive }\end{array}$ & $\begin{array}{l}\text { Relatively } \\
\text { high }\end{array}$ & $\begin{array}{l}\text { Life common } \\
\text { sense } \\
\text { propaganda, the } \\
\text { effect is not big }\end{array}$ \\
\hline 1 & $\begin{array}{l}\text { Good taste, } \\
\text { good for } \\
\text { health }\end{array}$ & $\begin{array}{l}\text { Heavy } \\
\text { metals and } \\
\text { pesticide } \\
\text { residues } \\
\text { were not } \\
\text { detected }\end{array}$ & $\begin{array}{l}\text { No foreign } \\
\text { body }\end{array}$ & $\begin{array}{l}\text { No } \\
\text { pathogenic } \\
\text { bacteria }\end{array}$ & high & $\begin{array}{l}\text { Conduct } \\
\text { propaganda to } \\
\text { promote the } \\
\text { formation of } \\
\text { vegetable safety } \\
\text { awareness }\end{array}$ \\
\hline
\end{tabular}

\section{To Establish a Vegetable Safety Risk Early Warning Model}

Based on the vegetable safety fault tree and risk analysis, the warning model is established in Fig. 4: 


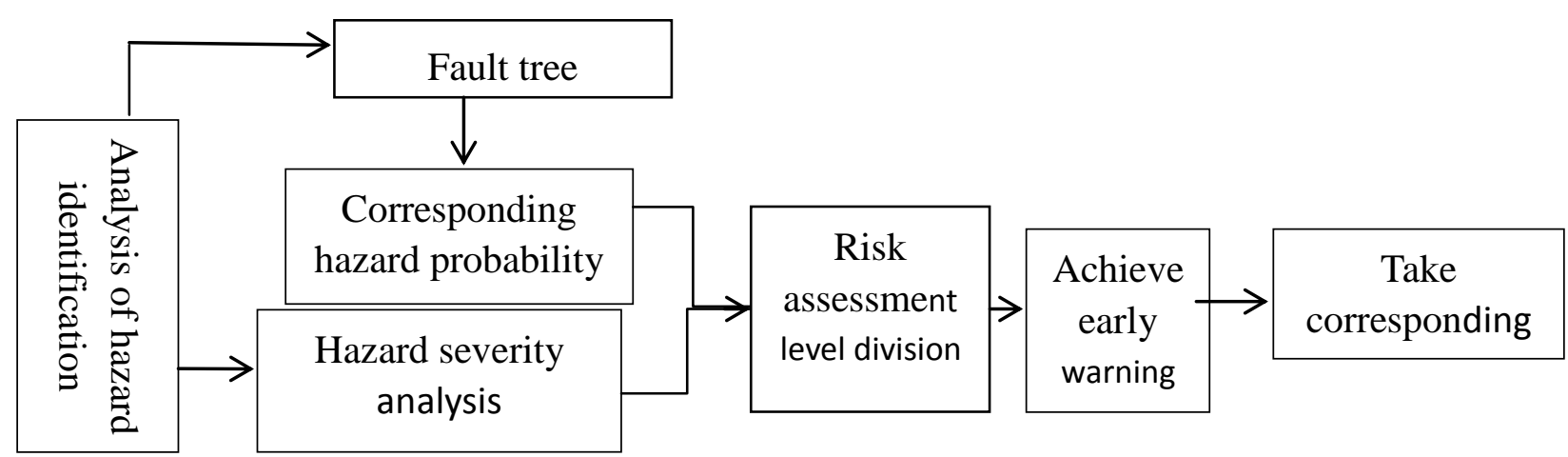

Figure 4. Early warning model of vegetable safety risk

\section{Acknowledgment}

This work was supported by Hebei province social science fund project (HB15GL131)

\section{References}

[1] Lv Ting-ting. Improve and perfect of our country's food safety regulatory system [J]. Journal of northeast agricultural university (social science edition), 2011, 9 (01):132 136.

[2] Roberts, Trends in food safety management in Victoria, Australia. International Journal of Contemporary Hospitality Management, 2004, 16(3):13 15.

[3] Ding Changdong. Problem of vegetable pesticide residue standard in our country and countermeasures $[\mathrm{J}]$, the quality and safety of agricultural products standardization column, 2004.3:12 14.

[4] Taylor. HACCP for the hospitality industry: a psychological model for success. International Journal of Contemporary Hospitality Management, 2008, 20(5), 508 523.

[5] Guo tao, zhi-yu zhao. Vehicle diesel engine fault diagnosis based on fault tree [J]. The digital world, 2016(9):124-126

[6] Li wen, elzanaty s. A method of fault tree analysis with time constraints [J]. Computer and modern, 2016(7):56-59

[7] Full China. Based on the fault tree of locomotive system level fault diagnosis technology research [J]. Journal of enterprise technology development, 2016(21):101-104.

[8] Guo Yongjin li-ping sun. Fault tree analysis method based on matrix [J]. Journal of Harbin engineering university, 2016(7):20-24.

[9] Wang wei, wang, de-wu huang. Small munitions fault tree analysis of system failure [J]. Journal of shenyang university of technology, 2010 (6):89-92.

[10]Guo Wenfeng. Fault tree analysis is used to analyse the bomb found at the bottom of the failure[J].Science and technology information.2012(19):121-126. 